\title{
DINAMIKA PEMIKIRAN KLASIFIKASI ILMU DALAM KHAZANAH INTELEKTUAL ISLAM KLASIK
}

\author{
Muhammad Zainal Abidin \\ Universitas Islam Negeri Antasari Banjarmasin \\ mzabidin@uin-antasari.ac.id
}

Diterima 16 Mei 2021 | Direview 01 Juni 2021 | Diterbitkan 30 Juni 2021

\begin{abstract}
The idea of science integration which is an important issue of Muslims today demands attention to the study of science classification. This topic is among the least touched in discussions related to Islam and science. This article is the result of a literature review that raises classical Muslim intellectual thoughts related to the classification of science. During the heyday of Islam, this issue received serious attention from many Muslim intellectuals at that time. The important findings from this paper are that: First, the repertoire of thought in the classification of science in Islam shows the great enthusiasm of Muslim scientists in the development of science whose impact can be felt today. Second, although there are various variations in the classification of science, they still provide respect and space for metaphysical or religious sciences. Third, there are two patterns in the classification of science as stated by Muslim scientists, some are strongly influenced by the Greek tradition, and some are based on Islamic treasures. This division in the present context, this idea is similar to the view of Islamization of science and the view of Islamic scholarship.
\end{abstract}

Keywords: Dinamika, Klasifikeasi, Ilmu, Islam Klasike

\section{Abstrak}

Gagasan integrasi ilmu yang menjadi isu penting umat Islam saat ini menuntut perhatian terhadap kajian klasifikasi ilmu. Topik ini termasuk yang kurang disentuh dalam diskusi terkait Islam dan ilmu pengetahuan. Artikel ini merupakan hasil kajian literatur yang mengangkat pemikiran intelektual muslim klasik terkait dengan klasifikasi ilmu. Pada masa kejayaan Islam, isu ini termasuk mendapat perhatian yang serius dari banyak intelektual muslim masa itu. Temuan penting dari tulisan ini bahwa: Pertama, khazanah pemikiran klasifikasi ilmu dalam Islam menunjukkan antusiasme besar para ilmuwan muslim dalam pengembangan ilmu yang dampaknya bisa dirasakan sampai saat ini. Kedua, meski ada ragam variasi klasifikasi ilmu, mereka tetap memberikan penghargaan dan ruang bagi ilmu-ilmu metafisika atau ilmu-ilmu keagamaan. Ketiga, ada dua pola dalam klasifikasi ilmu sebagaimana dikemukakan oleb ilmuwan muslim, ada yang dipengarubi kuat oleh tradisi Yunani, dan ada juga yang berpijak dari khazanah Islam. Pembagian ini dalam konteks sekarang, gagasan ini serupa dengan pandangan Islamisasi ilmu dan pandangan pegilmuan Islam

Kata Kunci: Dinamika, Klasifikasi, Ilmu, Islam Klasik

\section{Pendahuluan}

Gagasan klasifikasi ilmu kurang mendapatkan perhatian yang cukup serius dari kalangan ilmuwan muslim masa kini, minimnya perhatian ini kiranya menjadi satu indikator kurangnya apresiasi umat Islam terhadap ilmu-ilmu metodologi secara umum. Kajian-kajian di Barat sendiri terkait klasifikasi ilmu umumnya mengabaikan hasil-hasil karya intelektual muslim pada masa keemasannya. ${ }^{1}$ Pembagian klasik yang diawali dari gagasan Aristoteles umumnya langsung melompati ke model klasifikasi yang dilakukan Roger Bacon dan Francis Bacon. $^{2}$

Pemikiran Aristoteles terkait klasifikasi ilmu yang paling matang dari pemikiran filsafat Yunani klasik. ${ }^{3}$ Aristoteteles bisa disebut sebagai filosof pertama yang melakukan klasifikasi ilmu. Pengaruhnya sangat kuat merentang ke fase-fase sesudahnya. ${ }^{4}$ Secara umum,

${ }^{1}$ G. W. TROMPF, “The Classification of the Sciences and the Quest for Interdisciplinarity: A Brief History of Ideas from Ancient Philosophy to Contemporary Environmental Science," Environmental Conservation; Cambridge 38, no. 2 (June 2011): 113-26, http://dx.doi.org/10.1017/S0376892911000245.

2Perez Zagorin, "Francis Bacon's Concept of Objectivity and the Idols of the Mind," British Journal for the History of Science; Norwich 34, no. 123 (December 2001): 379-93, https://search.proquest.com/docview/215735755/abstract/B287F344C13A4053PQ/1.

3 Aristotle - Contemporary Perspectives on His Thought: On the 2400th Anniversary of Aristotle's Birth, vol. 2018

(Beaverton, United States, Beaverton: Ringgold Inc, 2018),
https://search.proquest.com/docview/2102009950/citation/7FC4DCA04AE24F7CPQ/11.

${ }^{4}$ Edith Hall, "'Master of Those Who Know': Aristotle as Role Model for the Twenty-First Century Academician," European Review; Cambridge 25, no. 1 (February 2017): 3-19, http://dx.doi.org/10.1017/S1062798716000429.; Enrico Berti, “The Contemporary Relevance of Aristotle's 
Aristoeteles membagi ilmu kepada dua bagian pokok, yang kemudian melahirkan sejumlah cabang lainnya: Pertama, ilmu teoritis. Jenis ilmu ini semata pengetahuan, yang terbagi pada tiga bagian: 1) ilmu metafisika/ filsafat/ ketuhanan (teologi) yaitu jenis ilmu yang membahas tentang wujud mutlak. 2) ilmu matematika, yakni pembahasan tentang wujud dari sudut ia adalah ukuran dan jumlah; 3) ilmu fisika, yakni pembahasan tentang wujud dari perspektif yang dapai diindera dan beergerak. Kedua, ilmu praktis. Tujuannya adalah pengetahuan untuk mengatur perbuatan manusia yang terbagi kepada empat bagian: 1) ilmu akhlak; 2) ilmu pengaturan rumah; 3) ilmu politik; dan 4) ilmu seni dan puisi. Adapun logika tidak termasuk dalam pembagian ini karena objeknya adalah pemikiran. Ia adalah instrumen untuk semua ilmu. ${ }^{5}$

Pemikiran Aristeteles sangat berpengaruh pada perkembangan klasifikasi ilmu di dunia Islam. Model klasifikasi ilmu Aristoteteles ini kemudian banyak diadopsi dan dikembangkan oleh para ilmuwan muslim seperti al-Farabi dan Ibnu Sina dengan tambahan beberapa modifikasi tertentu. Dalam tradisi ilmiah Islam, klasifikasi ilmu termasuk yang menjadi perhatian serius di kalangan intelektual Islam. ${ }^{6}$ Al Farabi dipandang sebagai figur awal yang secara sistematik melakukan klasifikasi ilmu ini secara mendalam dalam bukunya ihsha al 'ulum. ${ }^{7}$ Sesudah al Farabi, Ibnu Sina, Ikhwan al Shafa dan al Razi juga membuat klasifikasi ilmu, namun secara substanstif tidak berbeda jauh dengan yang dikemukakan oleh al Farabi.

Al Khawarizmi dalam kitabnya mafatih al ulum mengklasifikasi ilmu menjadi dua bagian utama, yakni: kelompok pertama, ilmu fikih, ilmu kalam, ilmu gramatika, ilmu al kitabah, ilmu syair dan arud, dan ilmu sejarah. Kelompok kedua, yaitu membahas mengenai ilmu filsafat, ilmu logika, kedokteran, aritmatika, geometri, astronomi, musik, dinamika, dan kimia. Ikhwan al Shafa dalam kitabnya Rasail Ikhwan al Shafa menulis satu pasal khusus tentang jenis-jenis ilmu. Mereka menulis tentang ilmu-ilmu apa saja yang perlu dipelajari, ilmu yang lebih dahulu dan penting untuk diketahui dan dipahami serta bagaimana hubungan antara satu ilmu dengan ilmu-ilmu yang lain. ${ }^{8}$

Beragamnya paparan dari sejumlah karya intelektual muslim terdahulu terkait klasifikasi ilmu menunjukkan perhatian terhadap perkembangan ilmu pengetahuan. Klasifikasi sederhana yang dirintis oleh al Kindi (w. $252 \mathrm{H}$ ), dilanjutkan dengan usaha al Farabi yang lebih serius dalam mendeskripsikan perkembangan dan pembagian ilmu pada masanya. Pengaruh Aristoteles cukup kental dalam mewarnai corak klasifikasi ilmu al Farabi, yang pada masa itu memang menjadi figur yang banyak menyita perhatian para sarjana muslim masa itu. ${ }^{9}$

Usaha klasifikasi Ibnu An Nadim sebagaimana disebut 'Abd al Majid an Najjar bisa dipandang sebagai model klasifikasi yang tumbuh dari realitas pemikiran Islam secara lebih otentik. Usaha ini kemudian tumbuh dan berkembang ke figur Ibnu Hazm dan al Abiyuri serta puncaknya pada Ibnu Khaldun yang model klasifikasnya lebih memberikan warna dan corak pemikiran Islam yang lebih jelas. Berikutnya, Thasy Kubri Zadah menawarkan model

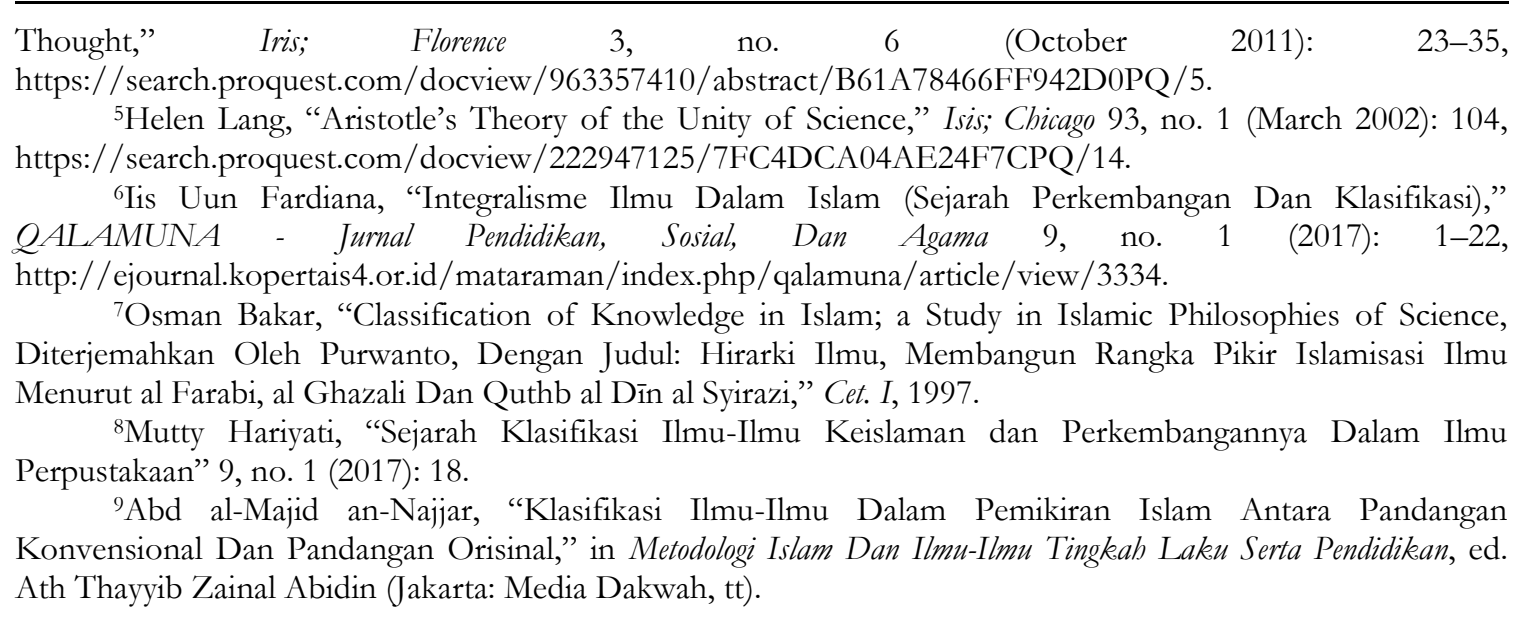


klasifikasi yang lebih komprehensif terkait warisan ilmiah Islam. Pada karyanya yang berjudul Miftah as Sa'adah didokumentasikan ilmu-ilmu yang ada dalam lingkaran kebudayaan Islam dengan sistem klasifikasi bermetode paling luas dan mencakup yang pernah dikenal dalam pemikiran Islam. Umumnya model klasifikasi yang muncul belakangan sesudah Ibnu Khaldun dan Thasy Kubri Zadah yang mensitasi dari pemikiran kedua tokoh tersebut. ${ }^{10}$

Perhatian yang serius terhadap klasifikasi ilmu ini mengingat bahwa klasifikasi ilmu memiliki tujuan penting untuk memberikan pengantar agar mereka yang ingin belajar mampu memilih sains apakah yang lebih utama, lebih bermanfaat, lebih dikuasai, lebih dekat, lebih tinggi lebih rendah, dan manakah yang terlebih dahulu dan penting dipelajari. Klasifikasi ilmu juga bermanfaat mengungkapkan berbagai cabang ilmu, yang masih tersembunyi atau disembunyikan sebagian kalangan.

\section{Metode}

Tulisan ini merupakan hasil penelitian literatur yang mengkaji pemikiran intelektual muslim klasik terkait dengan topik khazanah klasifikasi ilmu dalam Islam. Persoalan klasifikasi atau pembidangan ilmu dikaji dan dikembangkan oleh banyak ilmuwan muslim. Berikut ini ada 8 orang ilmuwan muslim yang akan disajikan pemikiran mereka terkait dengan klasifikasi ilmu. Mereka adalah al Farabi, Ibnu Sina, Ibnu al-Haytham, al Ghazali, Ibnu an Nadim, Ibnu Khaldun, Ibnu Hazm, dan Thasy Kubri Zadah. Pemikiran mereka kiranya dapat menjadi representasi dari gagasan klasifikasi ilmu pada masa periode klasik, yang pada masa sekarang dapat menjadi rujukan dalam ikhtiar pengembangan kelimuan di Perguruan Tinggi Keagamaan Islam (PTKI), khususnya yang berada di lingkungan Kementerian Agama Republik Indonesia. Secara berurutan gagasan klasifikasi ilmu tersebut dimulai dari figur al Farabi yang memberikan warna tersendiri dalam hal klasifikasi ilmu dan dilanjutkan dengan figur lainnya berdasarkan kronologi hidupnya.

\section{Hasil dan Pembahasan}

\section{Klasifikasi Ilmu al Farabi}

Abu Nashr Muhammad bin Muhammad Tarkhan bin Uzalag dilahirkan pada $259 \mathrm{H}$ (872 M) di Wasij, distrik Farab, Turkistan. Ayahnya berasal dari keturunan Persia dan ibunya berkebangsaan Turki. Wafat $339 \mathrm{H}(950 \mathrm{M})$ di Damaskus pada usia 80 tahun. Al-Farabi dijuluki sebagai Al-Mu'allim al-Tsani (guru kedua) filsafat, dan yang dipandang sebagai $A l$ Mu'allim al-Awwal (guru pertama) Aristoteles. Sewaktu waktu muda, al-Farabi bekerja sebagai hakim, tetapi karena minatnya yang kuat pada ilmu dan filsafat, dia meninggalkan pekerjaannya pada usia 40 tahun dan pergi ke Bagdad. Belajar nąhwu kepada Abu Bakar alSaraj dan belajar logika kepada Abu Bisyr bin Matta bin Yunus. Al Farabi tinggal di Bagdad selama 30 tahun untuk belajar, menulis, dan mengajar serta mensyarah buku-buku Aristoteles dan Plato, sehingga sangat terkenal. Ketika Bagdad kacau, setelah panglima Dailama Tauzun menurunkan Khalifah al Muttaqi pada 329, al Farabi pindah ke Damaskus dan tinggal di sana sendirian untuk membaca dan menulis. Hidupnya sangat miskin dan bekerja sebagai tukang kebun. Pada tahun $332 \mathrm{H}$ (945 M), al-Farabi pindah ke Damaskus dan berkenalan dengan Saifu al-Daulah al-Hamdani, Sultan Daulah Hamdaniah di Aleppo. Ia diberi kedudukan sebagai ulama istana. Al Farabi adalah tokoh yang senang menyendiri, zuhud, merenung dan berpikir serta menjauhi kehidupan mewah, foya-foya, dan materialistik. Dia tidak menikah, tidak menyimpan harta, dan selalu mengenakan pakaian sufi. $^{11}$

Al Farabi menguasai semua cabang filsafat, logika, fisika, ketuhanan, ilmu alam, kedokteran, kimia, ilmu perkotaan, ilmu lingkungan, fiqh, ilmu militer, dan musik. Klasifikasi

\footnotetext{
${ }^{10}$ an-Najjar, "Klasifikasi Ilmu-Ilmu Dalam Pemikiran Islam Antara Pandangan Konvensional Dan Pandangan Orisinal.”

${ }^{11}$ Muhammad Utsman Najati, Ad Dirasat an Nafsinnah 'Inda Ulama Muslimin (Al Qahirah: Dar Syuruq, 1993), 51-53.; Robert Hammond, The Philosophy of Al Farabi and Its Influence on Medieval Thought (S.1.: Literary licensing, 2013).
} 
ilmu yang dilakukan oleh al Farabi berangkat dari pembagian hirarki yang manjudat (status ontologis) pada 4 (empat) tingkatan, yakni: Allah, sebagai wajib al wujud, kemudian malaikat, benda langit (celestial) dan benda bumi (terestial). ${ }^{12}$ Secara hirarki keempat maujudat ini memberikan pengaruh kuat kepada level yang dibawahnya dan semakin tinggi hirarki semakin jelas juga status ontologis yang dimilikinya. Hirarki yang maujudat ini bisa dipadang sebagai basis ontologis dari klasifikasi ilmu yang dikemukakan oleh al Farabi. ${ }^{13}$

Tujuan klasifikasi ilmu menurut al Farabi pada bagian awal dari karyanya ibsha al 'ulum adalah untuk menyebutkan ilmu-ilmu yang diketahui secara umum satu persatu dan untuk memberikan survei umum masing-masing dari mereka. Hirarki dalam hal ini bergerak dari yang paling cerdas dan pengetahuan yang masuk akal, yakni matematika dan fisika dan pengetahuan yang tidak dapat dipahami oleh intelek dan indera, yaitu metafisika. ${ }^{14}$

Secara umum, al Farabi mengklasifikasi ilmu pada dua kelompok besar, yakni: 'aqliyyah (intelektual) dan naqliyyah (doktrinal), yang kemudian disebut dengan ilmu filsafat dan ilmu agama. Ilmu filsafat dibagi lagi menjadi dua bagian, teoritis dan praktis. Bagian dari ilmu teoritis yaitu metafisika, matematika, dan fisika serta logika (sebagai ilmu dan sebagai alat). Sedangkan pembagian ilmu praktis yaitu etika dan politik. Adapun kelompok ilmu-ilmu agama dibagi pada tiga macam, yaitu: ilmu kalam, fikih, dan kaidah bahasa. Ilmu kalam sama posisinya dengan ilmu metafisika yang objek kajiannya adalah Tuhan, sedangkan ilmu fikih posisinya serupa dengan ilmu praktis, yang menjelaskan tentang cara terbaik dalam memperoleh kesempurnaan. Adapun kaidah bahasa Arab, posisinya pararel dengan ilmu logika dalam ilmu intelektual. ${ }^{15}$

Selanjutnya, secara lebih detil pada bagian di bawah ini disajikan model klasifikasi ilmu yang dikemukakan oleh al Farabi dalam bentuk tabel sebagai berikut:

Tabel 1

Klasifikasi Ilmu Al Farabi

\begin{tabular}{|c|c|c|c|c|}
\hline Umum & Sub 1 & Sub 2 & Sub 3 & Sub 4 \\
\hline \multirow{3}{*}{$\begin{array}{l}\text { Ilmu } \\
\text { Agama }\end{array}$} & \multicolumn{4}{|l|}{ Kalam } \\
\hline & \multicolumn{4}{|l|}{ Fikih } \\
\hline & \multicolumn{4}{|c|}{ Kaidah Bahasa Arab } \\
\hline \multirow{5}{*}{$\begin{array}{l}\text { Ilmu } \\
\text { Filsafat }\end{array}$} & \multirow{5}{*}{ Teoritis } & Metafisika & \multicolumn{2}{|c|}{$\begin{array}{l}\text { Ontologi; Wujud Non Fisik dan tidak dalam } \\
\text { Fisik; dan Prinsip-prinsip Demonstrasi }\end{array}$} \\
\hline & & Matematika & \multicolumn{2}{|c|}{$\begin{array}{l}\text { Bilangan; Geometri; Optik; Astronomi; } \\
\text { Musik; Ukuran; dan Mekanika }\end{array}$} \\
\hline & & Fisika & \multicolumn{2}{|c|}{$\begin{array}{l}\text { Fisika Dasar; Benda Fisik Sederhana; Kejadian } \\
\text { dan Kehancuran; Benda fisik dari Unsur- } \\
\text { unsur; Aksiden dan Pengaruhnya; Minerologi; } \\
\text { Botani; Zoologi: Hewan dan Manusia }\end{array}$} \\
\hline & & Ilmu Alat & Logika & $\begin{array}{l}\text { Kategori; Hermeneutika; Qiyas; } \\
\text { Demonstrasi; Topika; Sofistika; } \\
\text { Retorika; Puitik }\end{array}$ \\
\hline & & & Bahasa & $\begin{array}{l}\text { Kata Tunggal, Kata Tersusun, } \\
\text { Kaidah Kata Tunggal; Kaidah } \\
\text { Kata Tersusun, Memperbaiki } \\
\text { Tulisan, Memperbaiki Bacaan, }\end{array}$ \\
\hline
\end{tabular}

${ }^{12}$ Muhammad Zainal Abidin, "Konsep Ilmu Dalam Islam: Tinjauan Terhadap Makna, Hakikat, Dan Sumber-Sumber Ilmu Dalam Islam,” Jurnal Ilmu Ushuluddin 10, no. 1 (2011): 107-120.

${ }^{13}$ Salminawati, Basis Ontologis Klasifikasi Ilmu Dalam Perspektif Islam (Studi Tentang Pemikiran Al-Farabi, AlGhazali, Dan Ibnu Khaldun), 2012.

${ }^{14} \mathrm{Al}$ Farabi, Ibsha al Ulum (Beirut: Maktabah al Hilal, 1996), 3.

${ }^{15}$ Humaidi, Paradigma Sains Integratif Al Farabi (Jakarta: Sadra Press, 2015), 76-77. 


\begin{tabular}{|l|l|l|l|l|}
\hline & & & dan Menyusun Syair \\
\cline { 2 - 4 } & \multirow{2}{*}{ Praktis } & Politik & \\
\cline { 3 - 4 } & & Etika & \multicolumn{3}{|c|}{} \\
\hline
\end{tabular}

\section{Klasifikasi Ilmu Ibnu Sina}

Ibnu Sina (Avicenna) (980-1037) adalah salah satu filsuf terkemuka dari masa keemasan tradisi Islam yang juga mencakup al-Farabi dan Ibn Rushd. Dia juga dikenal sebagai al-Sheikh al-Rais (Pemimpin di antara orang-orang bijak) gelar yang diberikan kepadanya oleh murid-muridnya. ${ }^{16}$

Klasifikasi ilmu yang dikemukakan oleh Ibnu Sina secara lebih khusus dan lengkap dapat ditelusuri pada karyanya yang berjudul Risalah fi Aqsam al 'Aqliyyah. Dalam karyanya ini, Ibnu Sina membagi ilmu hikmah pada dua kategori utama yang masing-masingnya memiliki cabang dan ranting. Pertama, kategori ilmu-ilmu teoritis murni. Tujuannya yaitu untuk mendapatkan kepercayaan yang meyakinkan tentang keadaan maujudat yang keberadaannya tidak tergantung pada perbuatan manusia, tetapi pada pemikiran semata. Jenis ilmu ini dibagi lagi menjadi tiga bagian, yakni: ilmu paling rendah, dinamakan ilmu fisika, ilmu pertengahan yang disebut ilmu riyadhi atau matematika, dan ilmu tertinggi yang dinamakan ilmu ilahi (ketuhanan).

Selanjutnya, setiap ilmu teoritis murni ini memiliki pembagian-pembagian induk dan cabangnya lagi dengan posisi ilmu tertinggi tetap pada ilmu ketuhanan dengan perincian sebagai berikut: 1) Pengamatan tentang pengetahuan pengertian umum semua maujudat, 2) pengamatan tentang pokok-pokok dan dasar-dasar seperti ilmu fisika, matematika, dan logika; 3) pengamatan tentang penetapan adanya Yang Maha Benar (al Haq) pertama dan pengesaan-Nya; 4) pengamatan tentang penetapan inti-inti kerohanian (malaikat); 5) pengamatan tentang pendayagunaan inti-inti dari benda-benda langit dan bumi terhadap intiinti kerohanian tersebut; 6) Pengetahuan tentang cara turunnya wahyu; 7) Pengetahuan pertemuan di akhirat (al ma'ad), yakni membahas tentang keadaan hari berbangkit seperti kebahagiaan dan kesengsaraan rohani yang dapat diketahui melalui akal dan kebahagiaan dan kesengsaraan rohani yang dapat diketahui melalui syara'. ${ }^{17}$

Kedua, ilmu-ilmu amali (praksis), yakni kategori ilmu yang bukan semata pemikiran murni, tetapi juga berkaitan dengan usaha. Ilmu ini bisa dikelompokkan lagi pada tiga bagian, yakni: 1) Ilmu Akhlak, yang melalui ilmu ini dapat diketahui bagaimana akhlak dan perbuatan sesorang sebagaimana terdapat pada buku Aristoteteles terkait dengan akhlak.; 2) Ilmu pengurusan rumah sebagaimana juga terdapat pada buku Aristeteles terkait dengan peraturan rumah; 3) Ilmu politik sipil seperti yang diuraikan oleh Plato dan Aristoteteles terkait dengan politik dan diikuti oleh hal-hal yang berhubungan dengan kenabian dan syariat.

Tabel 2

Klasifikasi Ilmu Ibnu Sina

\begin{tabular}{|c|l|l|l|}
\hline $\begin{array}{c}\text { Kategori } \\
\text { Umum }\end{array}$ & \multicolumn{1}{|c|}{ Sub 1 } & \multicolumn{1}{|c|}{ Sub 2 } & \multicolumn{1}{c|}{ Penjelasan } \\
\hline \multirow{4}{*}{ Ilmu Hikmah } & \multirow{2}{*}{\begin{tabular}{l} 
Murni Teoritis \\
\cline { 3 - 4 }
\end{tabular}} & Fisika \\
\cline { 3 - 4 } & & Katematika & $\begin{array}{l}\text { 1) Pengamatan tentang pengetahuan } \\
\text { pengertian umum semua maujudat; } \\
\text { 2) pengamatan tentang pokok-pokok }\end{array}$ \\
\hline
\end{tabular}

${ }^{16}$ Lihat "Ibn Sina - Islamic Philosophy Online," accessed October 15, 2019, http://muslimphilosophy.org/category/dudes/sina.

${ }^{17}$ Lihat an-Najjar, "Klasifikasi Ilmu-Ilmu Dalam Pemikiran Islam Antara Pandangan Konvensional Dan Pandangan Orisinal," 327-28. 


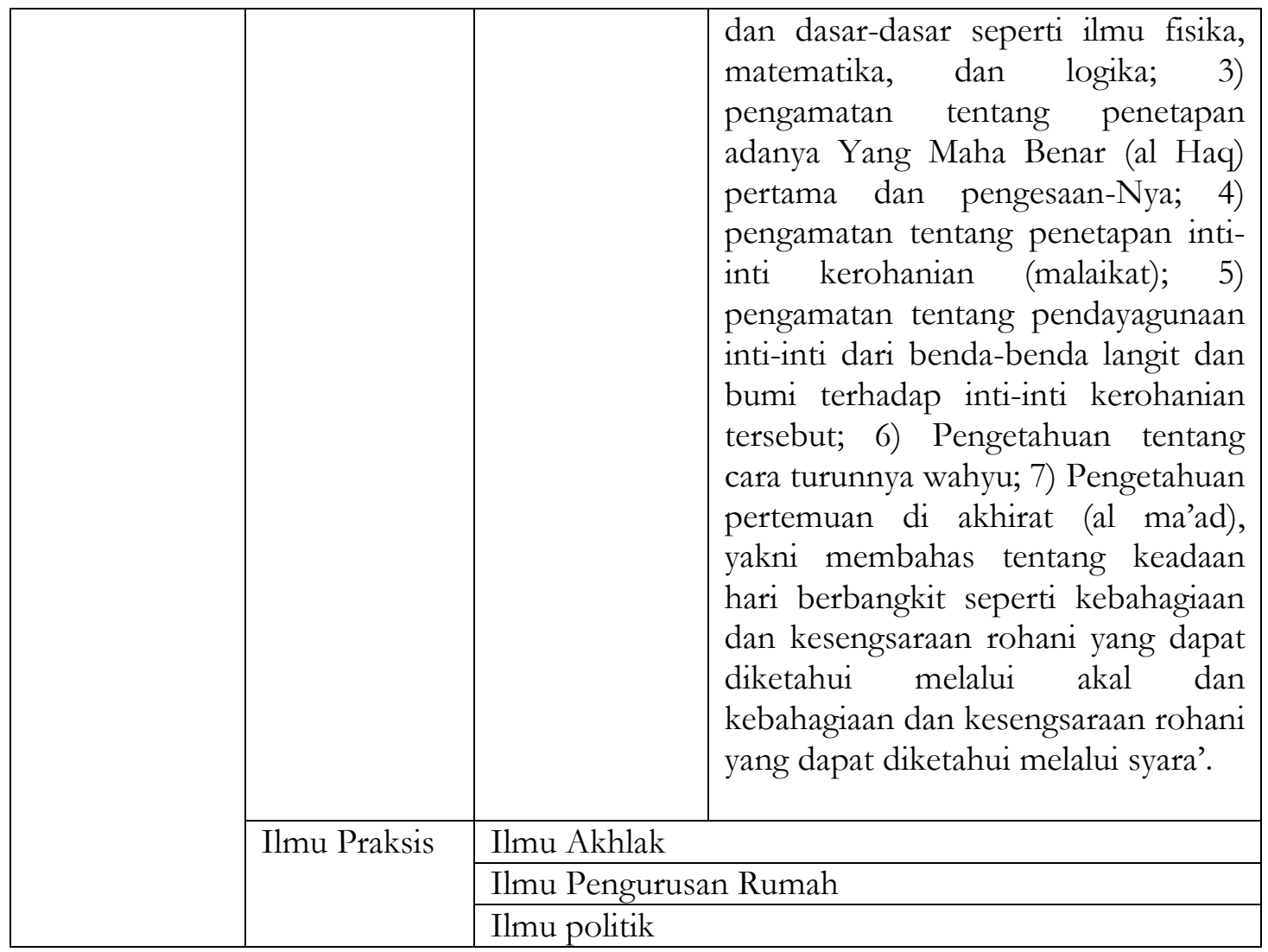

\section{Klasifikasi Ilmu Ibnu Haytham}

Nama lengkap Ibnu al-Haytham adalah Abū 'Alī al-Hasan ibn alHasan Ibn alHaytham. Ia dilahirkan di Basra, sekarang Irak, sekitar tahun 965 M.; oleh karena itu, ia juga dikenal sebagai al-Bașrī. Ibn al-Haytham juga dikenal di Barat sebagai Alhacen atau Alhazen berasal dari "al-Hasan". Nama "al-Haytham" sendiri diambil dari nama kakeknya. ${ }^{18}$

Ibn Haytham adalah seorang ahli matematika, astronom, dan fisikawan Arab dari Zaman Keemasan Islam. Kadang-kadang disebut sebagai "bapak optik modern", ia memberikan kontribusi yang signifikan terhadap prinsip-prinsip optik dan persepsi visual khususnya, karyanya yang paling berpengaruh adalah Kitab al-Manâzir (كتاب المناظر, Buku Optik "), ditulis selama 1011-1021, yang bertahan dalam edisi Latin. Sebagai seorang polymath, ia juga menulis tentang filsafat, teologi, dan kedokteran. Ibn al-Haytham adalah yang pertama menjelaskan bahwa penglihatan terjadi ketika cahaya memantul dari suatu objek dan kemudian beralih ke mata seseorang. Dia adalah orang pertama yang menunjukkan bahwa penglihatan terjadi di otak, bukan di mata. Dia juga merupakan pendukung awal konsep bahwa hipotesis harus dibuktikan dengan eksperimen berdasarkan prosedur yang dapat dikonfirmasi atau bukti matematis - karenanya memahami metode ilmiah lima abad sebelum ilmuwan Renaissance. Lahir di Basra, ia menghabiskan sebagian besar masa produktifnya di ibu kota Fatimiyah Kairo dan memperoleh penghasilan dengan menulis berbagai risalah dan mengajar para anggota kaum bangsawan. Ibn al-Haytham kadang-kadang diberi julukan al-Basri setelah tempat kelahirannya, atau al-Misri ("Mesir"). Ibn al-Haytham dijuluki "Ptolemeus Kedua" oleh Abu'l-Hasan Bayhaqi, dan "Fisikawan" oleh John Peckham. Ibn al-Haytham membuka jalan bagi ilmu modern optik fisik. ${ }^{19}$

${ }^{18}$ Usep Mohamad Ishaq and Wan Mohd Nor Wan Daud, "Ibn Al-Haytham's Classification of Knowledge,” Al-Jami'ah: Journal of Islamic Studies 55, no. 1 (June 26, 2017): 189-210, https://doi.org/10.14421/ajis.2017.551.189-210.
${ }^{19}$ Lihat "Ibn Al-Haytham,"
in Wikipedia, September
12
2019 https://en.wikipedia.org/w/index.php?title=Ibn_al-Haytham\&oldid=915333226. 
Pemikiran Ibn Haytham terkait dengan klasifikasi ilmu bisa dilihat pada pandangannya tentang hikmah. Bagi Ibn Haytham, ilmu pengetahuan bersumber dari Al-Hikmah, sebagaimana ungkapannya:

$$
\text { الحكمة علم كل حق و عمل كل نافع }
$$

"Al-hikmah adalah setiap pengetahuan sejati dan semua tindakan yang bermanfaat"

Berdasarkan pengertian kata al-Hikmah di atas, Ibn Haytham kemudian membagi ilmu pengetahuan menjadi dua bagian, yaitu; teori dan praktik. Secara teori, ilmu pengetahuan mengacu pada definisi علم كل حق (pengetahuan sejati) yang terbagi menjadi tiga cabang; pertama; matematika. Bagian yang termasuk dalam matematika ini seperti geometri, aritmatika, music, dan astronomi. Selanjutnya ia juga memasukkan disiplin ilmu lainnya kedalam sub-bagian dalam cabang matematika seperti geodesi, akunting, algebra, faraid, optik, timbangan, geometrik, mesin; Kedua; ilmu alam. Bagian ilmu alam ini adalah segala yang mencakup secara fisik dan yang tampak secara indrawi sebagai objek kajian dari ilmu pengetahuan; Ketiga, metafisika. Merupakan cabang ilmu yang membahas tentang realitas yang tidak bisa di indra, seperi sifat alam, sifat manusia, dan yang berkenaan dengan ketuhanan. Ketiga cabang ilmu ini ini merupakan ontologi dari pengetahuan yang dibangun oleh Ibn Haytham. ${ }^{20}$

Selanjutnya pengetahuan yang mengacu pada عمل كل نافع yang bermakna segala tindakan/perbuatan yang bermanfaat. Ilmu pengetahuan ini terbagi lagi menjadi dua, yakni ilmu pengetahuan yang bersifat individu dan yang bersifat kelompok. Pengetahuan bersifat individu adalah segala yang berkaitan dengan ilmu kesehatan dan budi pekerti (akhlak/moral). Sedangkan ilmu pengetahuan yang bersifat kelompok, seperti keluarga, administrasi perkantoran, politik, hukum dan hukuman. ${ }^{21}$

Tabel 3

Klasifikasi Ilmu Ibnu Haytham

\begin{tabular}{|c|c|c|c|c|}
\hline Umum & Sub 1 & Sub 2 & Sub 3 & Sub 4 \\
\hline \multirow{5}{*}{$\begin{array}{c}\text { Al- } \\
\text { Hikmah }\end{array}$} & \multirow{3}{*}{ Teori } & Matematika & $\begin{array}{l}\text { Geometri } \\
\text { Aritmatika } \\
\text { Music } \\
\text { astronomi }\end{array}$ & $\begin{array}{l}\text { Geodesi, Akunting, } \\
\text { Algebra, Faraid, } \\
\text { Optik, Timbangan, } \\
\text { Geometric, Mesin }\end{array}$ \\
\hline & & Ilmu alam & $\begin{array}{l}\text { Yang bersifat fisik, } \\
\text { objek yang nampak } \\
\text { yang mampu di } \\
\text { ketahui melalui indra }\end{array}$ & \\
\hline & & Metafisika & $\begin{array}{l}\text { Sifat alam } \\
\text { Sifat Manusia } \\
\text { Ketuhanan } \\
\end{array}$ & \\
\hline & & Individu & $\begin{array}{l}\text { Kesehatan } \\
\text { Moral/Akhlak }\end{array}$ & \\
\hline & Praktik & Kelompok & $\begin{array}{l}\text { Keluaraga } \\
\text { Admnistrasi } \\
\text { pemerintahan } \\
\text { Politik } \\
\text { Hukum } \\
\text { Hukuman }\end{array}$ & \\
\hline
\end{tabular}

\section{Klasifikasi Ilmu Al Ghazali}

${ }^{20}$ Ishaq and Daud, "Ibn Al-Haytham's Classification of Knowledge," 194.

${ }^{21}$ Ishaq and Daud, 195. 
Al Ghazali adalah salah satu filosuf, teolog, ahli hukum, dan mistikus yang paling menonjol dan berpengaruh dari Islam Sunni. Ia berasal dari Persia. Karya-karyanya sangat diakui oleh orang-orang sezamannya sehingga al-Ghazali dianugerahi gelar kehormatan Hujjat al-Islam. Al Ghazali percaya bahwa tradisi spiritual Islam telah menjadi hampir mati dan bahwa ilmu-ilmu spiritual yang diajarkan oleh generasi pertama Muslim telah dilupakan. Sehingga lahirlah magnum opus berjudul Ihya Ulîm al Dîn. Di antara karya-karyanya yang lain, Tabâfut al-Falâsifa adalah tonggak penting dalam sejarah filsafat, karena memajukan kritik ilmu pengetahuan Aristoteles yang dikembangkan kemudian di Eropa abad ke-14. ${ }^{22}$

Imam Al Ghazali mendefinisikan al-ilm sebagai representasi dari jiwa yang rasional dan tenang terhadap makna sebenarnya dari segala yang tampak, bentuk lahiriah mereka. Dengan kata lain objek kajian ilmu pengetahuan akan menjadi sebuah ilmu pengetahuan setelah melalui proses memahami arti, tujuan, kuantitas, substansi, dan esensi yang dapat dinalar setelah dipersepsi oleh akal dan jiwa yang tenang. Dalam hal ini Imam Al Ghazali mengklasifikasikan ilmu menjadi dua, yakni Fardhu 'Ain yang berkenaan dengan i'tiqad, amal, larangan dan Fardhu Kifayah yang dipelajari secukupnya. Fardhu 'Ain mencakup ilmu yang berkaitan dengan esoterik (mukasyafah), mencakup tentang makna kenabian, makna wahyu, malaikat, mizan, sirat, permusuhan setan dengan malaikat, dan seterusnya. Klasifikasi ini bertumpu segala makna yang tersembunyi oleh sebab itu disuruh untuk mencarinya. Sedangkan Fardbu Kifayah merupakan ilmu yang mempunyai otoritas dalam praktik-praktik ibadah. Di dalamnya terdapat korelasi antara doktrin dan praktik. Tujuannya menyelamatkan jiwa agar mendapatkan kebahagiaan di akhirat. ${ }^{23}$

Tabel 4

Klasifikasi Ilmu Al Ghazali

\begin{tabular}{|c|c|c|c|c|c|}
\hline Umum & Sub 1 & \multicolumn{2}{|c|}{ Sub 2} & Sub 3 & Ket \\
\hline \multirow{3}{*}{ Ilmu } & $\begin{array}{c}\text { Fardhu 'Ain } \\
\text { yang } \\
\text { berkenaan } \\
\text { dengan } \\
\text { I'tiqad, } \\
\text { Amal, } \\
\text { Larangan }\end{array}$ & \multicolumn{2}{|c|}{$\begin{array}{c}\text { Mukasyafah } \\
\text { (esoterik) }\end{array}$} & $\begin{array}{l}\text { makna kenabian, } \\
\text { makna wahyu, } \\
\text { malaikat, mizan, } \\
\text { sirat, permusuhan } \\
\text { setan dengan } \\
\text { malaikat, dst }\end{array}$ & Kasyf \\
\hline & \multirow[t]{2}{*}{$\begin{array}{c}\text { Fardhu } \\
\text { Kifayah } \\
\text { yang } \\
\text { dipelajari } \\
\text { secukup nya }\end{array}$} & $\begin{array}{l}\text { ilmu- } \\
\text { ilmu } \\
\text { agama }\end{array}$ & $\begin{array}{c}\text { Usul } \\
\text { (pokok) } \\
\text { Furu' } \\
\text { (cabang) } \\
\text { Muqaddim } \\
\text { ah } \\
\text { (prasarana) } \\
\text { Mutammi } \\
\text { mat } \\
\text { (Pelengkap } \\
\text { ) }\end{array}$ & $\begin{array}{l}\text { ilmu tafsir, hadith, } \\
\text { fiqh, usul al-fiqh, } \\
\text { dan lain-lain }\end{array}$ & $\begin{array}{l}\text { Berkenaan } \\
\text { dengan industri, } \\
\text { seperti pertanian, } \\
\text { tekstil, desain } \\
\text { busana }\end{array}$ \\
\hline & & Non- & yang & Kedokteran, & \\
\hline
\end{tabular}

22“Al-Ghazali," in Wikipedia, September 9, 2019, https://en.wikipedia.org/w/index.php?title=AlGhazali\&oldid=914874920.

${ }^{23}$ Indra Ari Fajari, "KLASIFIKASI ILMU PENGETAHUAN MENURUT IMĀM Al-GHAZĀLĪ," Kontemplasi: Jurnal Ilmu-Ilmu Ushuluddin 4, no. 2 (December 1, 2016): 299-316-316, https://doi.org/10.21274/kontem.2016.4.2.299-316. 


\begin{tabular}{|l|c|c|l|l|}
\hline & agama & berasal & aritmatika, politik, & \\
& dari hasil & logika, bahasa & \\
& penalaran & & \\
& & akal \\
& manusia, & & \\
& & & & \\
& & pengalama \\
& nercobaan. & & \\
& & & \\
\hline
\end{tabular}

\section{Klasifikasi Ilmu Ibnu an Nadim}

Klasifikasi ilmu yang dilakukan Ibnu an Nadim dapat ditelusuri pada karyanya yang masyhur yaitu al Fibrist. Buku ini sebenarnya bukanlah buku khusus terkait klasifikasi ilmu, tetapi sebuah buku yang memaparkan pengetahuan yang tersebar di masyarakat Islam, yang meliputi berbagai ilmu dan aliran, berbagai ilmu dan karangan. Ibnu an Nadim sendiri menyebutkan bahwa bukunya tersebut adalah indeks buku-buku dari semua bangsa, baik arab atau 'ajam, yang sebagiannya berbahasa arab dan tulisannya dalam macam-macam ilmu, informasi tentang pengarang, tingkatan dan riwayat hidup pengarang, sejak ilmu itu dicipatakan sampai masa kita ini (Ibnu an Nadim). ${ }^{24}$

Al Fihrist terdiri dari sepuluh fasal dan setiap fasal dikhususkan untuk salah satu ilmu dasar, pertumbuhan, keterangan dan kutipan serta penjelasan seputar buku-buku penting yang pernah ditulis. Pengelompokkan fasal tersebut adalah sebagai berikut: 1) Bahasa-bahasa dari berbagai bangsa, kitab-kitab agama, al Qur'an dan Ilmu al Qur'an; 2) Gramatika dan hali gramatika; 3) Riwayat-riwayat sejarah (akhbar), sastera, sejarah dan keturunan-keturunan; 4) Syair dan penyair; 5) Kalam dan mutakallimun; 6) Fiqh, Fuqaha', Hadits dan Muhaddits; 7) Filsafat dan Ilmu-Ilmu Klasik; 8) Hiburan-hiburan, khurafat, permintaan-permintaan, sihir dan sebangsanya; 9) Aliran-aliran; 10) Informasi para ahli kimia dan industri. ${ }^{25}$

Tabel 5

Klasifikasi Ilmu Ibnu An Nadim

\begin{tabular}{|l|l|}
\hline Umum & \multicolumn{1}{|c|}{ Rincian } \\
\hline \multirow{5}{*}{ ILMU } & $\begin{array}{l}\text { Bahasa-bahasa dari berbagai bangsa, kitab-kitab agama, al Qur'an } \\
\text { dan Ilmu al Qur'an }\end{array}$ \\
\cline { 2 - 3 } & Gramatika dan hali gramatika \\
\cline { 2 - 3 } & $\begin{array}{l}\text { Riwayat-riwayat sejarah (akhbar), sastera, sejarah dan keturunan- } \\
\text { keturunan }\end{array}$ \\
\cline { 2 - 2 } & Syair dan penyair \\
\cline { 2 - 2 } & Kalam dan mutakallimun \\
\cline { 2 - 2 } & Figh, Fuqaha', Hadits dan Muhaddits \\
\cline { 2 - 2 } & Filsafat dan Ilmu-Ilmu Klasik \\
\cline { 2 - 2 } & $\begin{array}{l}\text { Hiburan-hiburan, khurafat, permintaan-permintaan, sihir dan } \\
\text { sebangsanya }\end{array}$ \\
\cline { 2 - 2 } & Aliran-aliran \\
\cline { 2 - 2 } & Informasi para ahli kimia dan industri. \\
\hline
\end{tabular}

\section{Klasifikasi Ilmu Ibn Khaldun}

Nama lengkap Ibnu Khaldun adalah Abu Zayd 'Abd al-Rahman ibn Muhammad ibn Khaldun al-Hadrami, lahir pada 27 Mei 1332 dan meninggal 19 Maret 1406 pada umur 73

${ }^{24}$ an-Najjar, "Klasifikasi Ilmu-Ilmu Dalam Pemikiran Islam Antara Pandangan Konvensional Dan Pandangan Orisinal," 342-43.

${ }^{25}$ an-Najjar, 343. 
tahun. Beliau adalah seorang sejarawan muslim dari Tunisia dan sering juga disebut sebagai bapak pendiri ilmu historiografi, sosiologi dan ekonomi. Karyanya yang terkenal adalah Muqaddimab. ${ }^{26}$

Bagi ibn Khaldun, ilmu pengetahuan terbagi dalam dua bagian; pertama, Naqliyah yang berdasarkan otoritas atau ilmu tradisional. Dalam hal ini, metode naqliyah melahirkan ilmuilmu, seperti Alqur'an dan ilmu Alqur'an, Tafsir, hadis dan ilmu hadis, ilmu hukum, ushul fiqh, dan fiqh, teologi, ilmu tasawuf dan bahasa; kedua, Aqliyah yang berdasarkan akal atau dalil rasional. Metode pengetahuan ini adalah Logika, Ilmu Alam, Metafisika, Matematika. Dari beberapa metode inilah yang kemudian melahirkan beberapa ilmu seperti Logika, fisika, kedokteran, pertanian, ilmu sihir, ilmu ghaib, kimia, kuantitas (ukur, bidang, ruang), musik, ilmu hitungan (matematika), astronomi. ${ }^{27}$

Tabel 6

Klasifikasi Ilmu Ibnu Khaldun

\begin{tabular}{|l|l|l|}
\hline \multicolumn{1}{|c|}{ Umum } & \multicolumn{1}{|c|}{ Sub 1 } & \multicolumn{1}{c|}{ Sub 2 } \\
\hline $\begin{array}{l}\text { Naqliyah } \\
\text { (berdasarkan } \\
\text { otoritas atau ilmu } \\
\text { tradisional) }\end{array}$ & $\begin{array}{l}\text { Hikmah dan } \\
\text { falsafah }\end{array}$ & $\begin{array}{l}\text { Alqur'an dan ilmu Alqur'an, Tafsir, hadis dan } \\
\text { ilmu hadis, ilmu hukum, ushul fiqh, dan fiqh, } \\
\text { teologi, ilmu tasawuf dan bahasa }\end{array}$ \\
\hline $\begin{array}{l}\text { Aqliyah } \\
\text { (berdasarkan akal } \\
\text { atau dalil rasional) }\end{array}$ & $\begin{array}{l}\text { Logika, Ilmu Alam, } \\
\text { Metafisika, } \\
\text { Matenatika }\end{array}$ & $\begin{array}{l}\text { Logika, fisika, kedokteran, pertamian, ilmu sihir, } \\
\text { ilmu ghaib, kimia, kuantitas (ukur, bidang, } \\
\text { ruang), musik, ilmu hitungan (matematika), } \\
\text { astronomi }\end{array}$ \\
\hline
\end{tabular}

\section{Klasifikasi Ilmu Ibnu Hazm}

Ibnu Hazm adalah seorang sejarawan, ahli fikih, dan imam Ahlus Sunnah di Spanyol Islam. Nama lengkapnya adalah Abu Muhammad Ali bin Ahmad bin Said bin Hazm. Ia dilahirkan pada 7 November 994 M di Córdoba, Kekhilafahan Kordoba dan wafat pada 15 Agustus 1064, di Mantha Lisha, dekat Sevilla. Ia dikenal sangat luas ilmu pengetahuannya dan produktif, dan pakar dalam bahasa Arab. Karya tulisnya disebutkan sebanyak 400 judul, meski kini yang masih dapat ditemui hanya 40 judul saja, mencakup berbagai topik seperti hukum Islam, sejarah, etika, perbandingan agama, akidah dan lain-lain. ${ }^{28}$

Ibnu Hazm menuliskan secara khusus 2 buah risalah terkait klasifikasi ilmu, yakni Risalah at Taufik dan Risalah Maratib al'Ulum. Klasifikasinya didasarkan pada 2 kategori utama, yakni: Jenis bermanafaat yang terpuji yang masuk dalam lingkaran akal dan syara', serta berikutnya jenis tercela yang keluar dari lingkaran akal dan syara'. ${ }^{29}$

Jenis terpuji dibagi lagi pada bagian utama, yakni ilmu khusus tentang syariat Islam yang meliputi: 1) Ilmu al Qur'an; 2) Ilmu Hadits; 3) Ilmu Fiqh; 4) Ilmu Nahwu; 5) Ilmu Bahasa; dan 6) Ilmu Akhbar. Berikutnya ilmu yang mencakup seluruh bangsa dengan pembagian: 1) Astronomi; 2) Ilmu Matematika; 3) Filsafat; 4) Kedokteran; dan 5) Puisi, retorika dan ilmu ungkapan.

Kedua bagian kelompok ilmu terpuji ini tidak terpisah antara satu dengan yang lainnya, tetapi merupakan kesatuan teratur yang utuh yang terhimpun dalam 7 macam ilmu,

26"Ibnu Khaldun," in Wikipedia bahasa Indonesia, ensiklopedia bebas, April 3, 2019, https://id.wikipedia.org/w/index.php?title=Ibnu_Khaldun\&oldid=14967599.

${ }^{27}$ an-Najjar, "Klasifikasi Ilmu-Ilmu Dalam Pemikiran Islam Antara Pandangan Konvensional Dan Pandangan Orisinal," 345.

${ }^{28}$ Lihat "Ibnu Hazm," in Wikipedia bahasa Indonesia, ensiklopedia bebas, September 24, 2018, https://id.wikipedia.org/w/index.php?title=Ibnu_Hazm\&oldid=14210662.

${ }^{29}$ an-Najjar, "Klasifikasi Ilmu-Ilmu Dalam Pemikiran Islam Antara Pandangan Konvensional Dan Pandangan Orisinal," 344. 
yakni: 1) Ilmu Syariat; 2) Ilmu Bahasa; 3) Ilmu Akhbar; 4) Ilmu Bintang; 5) Ilmu Hitung; 6) Ilmu Kedokteran; dan 7) Ilmu Filsafat.

Sedangkan pada ilmu kategori yang tidak terpuji meliputi 4 bagian ilmu, yakni: 1) Sihir; 2) Thalmasat; 3) Kimia; dan 4) Perbintangan (astrologi).

Tabel 7

Klasifikasi Ilmu Ibnu Hazm

\begin{tabular}{|c|c|c|c|}
\hline Umum & Sub 1 & Sub 2 & Penjelasan \\
\hline \multirow{11}{*}{ TERPUJI } & \multirow[t]{6}{*}{ Syariat Islam } & Ilmu al Qur'an & \multirow[t]{3}{*}{ Ilmu Syariat } \\
\hline & & Ilmu Hadits & \\
\hline & & Ilmu Fiqh & \\
\hline & & Ilmu Nahwu & \multirow[t]{2}{*}{ Ilmu Bahasa } \\
\hline & & Ilmu Bahasa & \\
\hline & & Ilmu Akhbar & Ilmu Akhbar \\
\hline & \multirow[t]{5}{*}{ Seluruh Bangsa } & Astronomi & Ilmu Bintang \\
\hline & & Ilmu Matematika & Ilmu Hitung \\
\hline & & Filsafat & Ilmu Filsafat \\
\hline & & Kedokteran & \multirow[t]{2}{*}{ Ilmu Kedokteran } \\
\hline & & $\begin{array}{lr}\text { Puisi, } & \text { retorika } \\
\text { dan } & \text { ilmu } \\
\text { ungkapan } & \end{array}$ & \\
\hline \multirow{4}{*}{$\begin{array}{l}\text { TIDAK } \\
\text { TERPUJI }\end{array}$} & Sihir & & \\
\hline & Thalmasat & & \\
\hline & Kimia & & \\
\hline & $\begin{array}{l}\text { Perbintangan } \\
\text { (astrologi). }\end{array}$ & & \\
\hline
\end{tabular}

\section{Klasifikasi Ilmu Thasy Kubri Zadah}

Kitab Miftah as Sa'adah wa Mishbah as Siyadah fi Mawdhuat al Ulum yang ditulis oleh Ahmad bin Mushthafa yang lebih dikenal sebagai Thasy Kubri Zadah dapat disebut sebagai ensiklopedi Islam terbesar dalam hal klasifikasi ilmu. Ahmad bin al Mushthafa mendasarkan klasifikasinya berdasarkan tingkatan wujud. Menurutnya ada 4 tingkatan wujud, yakni: kitabah (penulisan), 'ibarah (ungkapan), ad₹̧an (pemikiran) dan a'yan (tokoh-tokoh). Seluruh ilmu berkenaan dengan empat tingkatan ini. Pada tiga tingkatan pertama, ilmu berhubungan dengan ilmu alat. Sedangkan pada tingkatan yang keempat, ilmu yang berhubungan dengan meliputi ilmu praktis dan ilmu teoritis. Kedua jenis ilmu ini adakalanya bersesuaian dengan syara' atau bersesuaian dengan akal. ${ }^{30}$

Selanjutnya, ilmu dibagi lagi pada tujuh bagian yang dinamakan dahan dan cabangcabang yang lebih spesifik lagi. Pertama, Ilmu-ilmu tulisan yang memiliki dua cabang: 1) Ilmu-ilmu yang berhubungan dengan cara keahlian penulisan dan 2) Ilmu-ilmu yang berhubungan dengan huruf-huruf mufrad. Kedua, ilmu-ilmu yang berhubungan dengan kata- 
kata yang mempunyai tiga cabang, yakni: 1) Ilmu-ilmu yang berhubungan dengan mufrad; 2) Ilmu-imu yang berhubungan dengan murakabat (kata majemuk); dan 3) Cabang-cabang ilmu kearaban. Ketiga, Ilmu-ilmu yang membahas al Ma'qulat kedua dalam pemikiran dengan cabang sebagai berikut: 1) Ilmu-ilmu yang mencegah kesalahan dalam berlogika dan 2) Ilmuilmu yang mencegah kesalahan dalam perdebatan dan pelajaran seperti pengamatan, ilmu perdebatan dan ilmu perbedaan pendapat. Keempat, ilmu-ilmu rasional dengan cabangcabangnya yang terpenting yaitu: 1) Ilmu-ilmu ketuhanan, 2) Ilmu fisika, dan 3) Ilmu matematika. Kelima, Ilmu-ilmu amali (terapan) dengan cabang-cabangnya terpenting yaitu: 1) Ilmu-ilmu akhlak; 2) Ilmu-ilmu pengaturan rumah; 3) ilmu-ilmu politik. Keenam, ilmu-ilmu syar'iyyah dengan cabang-cabangnya yang terpenting yaitu: 1) Ilmu qira'at; 2) Ilmu riwayat hadits; 3) Ilmu tafsir al Qur'an, 4) Ilmu dirayah Hadits; 5) Ilmu Ushuluddin; 6) Ilmu Ushul Fiqh; 7) Ilmu Fiqh. Ketujuh, ilmu-ilmu batin, akhlak dan tasawuf yang cabang terpentingnya: 1) Ibadah; 2) Adat: 3) Mublakat, dan 4) Munjizyat. ${ }^{31}$

Tabel 10

Klasifikasi Ilmu Thasy Kubri Zadah

\begin{tabular}{|c|c|c|}
\hline Umum & Sub 1 & Sub 2 dan Penjelasan \\
\hline \multirow[t]{2}{*}{ Kitabah } & \multirow[t]{2}{*}{$\begin{array}{l}\text { Ilmu-ilmu } \\
\text { tulisan }\end{array}$} & $\begin{array}{l}\text { Ilmu-ilmu yang berhubungan dengan cara keahlian } \\
\text { penulisan }\end{array}$ \\
\hline & & $\begin{array}{l}\text { Ilmu-ilmu yang berhubungan dengan huruf-huruf } \\
\text { mufrad. }\end{array}$ \\
\hline \multirow[t]{3}{*}{ 'Ibarah } & \multirow{3}{*}{$\begin{array}{l}\text { Ilmu-ilmu yang } \\
\text { berhubungan } \\
\text { dengan kata- } \\
\text { kata }\end{array}$} & Ilmu-ilmu yang berhubungan dengan mufrad; \\
\hline & & $\begin{array}{l}\text { Ilmu-imu yang berhubungan dengan murakabat (kata } \\
\text { majemuk); }\end{array}$ \\
\hline & & Cabang-cabang ilmu kearaban. \\
\hline \multirow[t]{2}{*}{ Adzhan } & \multirow{2}{*}{$\begin{array}{l}\text { Ilmu-ilmu yang } \\
\text { membahas al } \\
\text { Ma'qulat }\end{array}$} & Ilmu-ilmu yang mencegah kesalahan dalam berlogika \\
\hline & & $\begin{array}{l}\text { Ilmu-ilmu yang mencegah kesalahan dalam perdebatan } \\
\text { dan pelajaran seperti pengamatan, ilmu perdebatan dan } \\
\text { ilmu perbedaan pendapat. }\end{array}$ \\
\hline \multirow[t]{15}{*}{ A'yan } & \multirow{3}{*}{$\begin{array}{l}\text { ilmu-ilmu } \\
\text { rasional }\end{array}$} & Ilmu-ilmu ketuhanan, \\
\hline & & Ilmu fisika, dan \\
\hline & & Ilmu matematika. \\
\hline & \multirow{3}{*}{$\begin{array}{l}\text { Ilmu-ilmu amali } \\
\text { (terapan) }\end{array}$} & Ilmu-ilmu akhlak; \\
\hline & & Ilmu-ilmu pengaturan rumah; \\
\hline & & Ilmu-ilmu politik. \\
\hline & \multirow{7}{*}{$\begin{array}{l}\text { Ilmu-ilmu } \\
\text { syar'iyyah }\end{array}$} & Ilmu qira'at; \\
\hline & & Ilmu riwayat hadits; \\
\hline & & Ilmu tafsir al Qur'an, \\
\hline & & Ilmu dirayah Hadits; \\
\hline & & Ilmu Ushuluddin; \\
\hline & & Ilmu Ushul Fiqh; \\
\hline & & Ilmu Figh. \\
\hline & \multirow{2}{*}{$\begin{array}{l}\text { ilmu-ilmu batin, } \\
\text { akhlak dan }\end{array}$} & Ibadah; \\
\hline & & Adat: \\
\hline
\end{tabular}




\begin{tabular}{|l|l|l|}
\hline & tasawuf & Muhlakat \\
\cline { 3 - 3 } & & Munjiyyat. \\
\hline
\end{tabular}

\section{Penutup}

Sebagai catatan penutup dari pembahasan tentang pembidangan atau klasifikasi ilmu dalam rentang sejarah Islam sebagaimana dikemukakan di atas bahwa: Pertama, perhatian terhadap klasifikasi ilmu sangat terkait dengan perhatian yang serius terhadap ilmu. Pada masa kejayaan Islam (the golden age of Islam) kita menemukan sejumlah karya besar terhadap klasifikasi ilmu yang pada saat bersamaan juga menunjukkan antusiasme besar para ilmuwan muslim dalam pengembangan ilmu yang dampaknya bisa dirasakan sampai saat ini. Kedua, meski ada banyak variasi dalam penyusunan klasifikasi ilmu, dapat ditegaskan bahwa semua mereka tetap memberikan penghargaan dan ruang bagi ilmu-ilmu metafisika atau ilmu-ilmu keagamaan. Bahkan sebagiannya sangat serius dalam hal ini. Pemikiran ini tentunya sangat kontras dengan pandangan Barat yang membatasi ilmiah hanya pada aspek-aspek yang bisa diobservasi dan diukur, serta mengeluarkan aspek-aspek yang diluarnya, terlebih pada urusan ilmu-ilmu agama atau metafisikan sebagai kawasan yang tidak ilmiah. Ketiga, ada dua pola dalam klasifikasi ilmu sebagaimana dikemukakan oleh ilmuwan muslim, ada yang dipengaruhi kuat oleh tradisi Yunani, dan ada juga yang berpijak dari khazanah Islam. Pembagian ini dalam konteks sekarang, gagasan ini serupa dengan pandangan Islamisasi ilmu dan pandangan pegilmuan Islam.

\section{Daftar Pustaka}

Al-Haytham, Ibn" in Wikipedia, September 12, 2019, https://en.wikipedia.org/w/index.php?title=Ibn_al-Haytham\&oldid=915333226.

"Al-Ghazali," in Wikipedia, September 2019, https://en.wikipedia.org/w/index.php?title=Al-Ghazali\&oldid=914874920.

Al-Majid an-Najjar, Abd, "Klasifikasi Ilmu-Ilmu Dalam Pemikiran Islam Antara Pandangan Konvensional Dan Pandangan Orisinal," in Metodologi Islam Dan Ilmu-Ilmu Tingkah Laku Serta Pendidikan, ed. Ath Thayyib Zainal Abidin (Jakarta: Media Dakwah, tt).

Ari Fajari, Indra, "KLASIFIKASI ILMU PENGETAHUAN MENURUT IMĀM AlGHAZĀLI,", Kontemplasi: Jurnal Ilmu-Ilmu Ushuluddin 4, no. 2 (December 1, 2016): 299-316-316, https://doi.org/10.21274/kontem.2016.4.2.299-316.

Aristotle - Contemporary Perspectives on His Thought: On the 2400th Anniversary of Aristotle's Birth, vol. 2018 (Beaverton, United States, Beaverton: Ringgold Inc, 2018), https://search.proquest.com/docview/2102009950/citation/7FC4DCA04AE24F7C $\mathrm{PQ} / 11$.

Farabi, Al, (1996). Ihsha al Ulum (Beirut: Maktabah al Hilal.

G. W. TROMPF, (2011). "The Classification of the Sciences and the Quest for Interdisciplinarity: A Brief History of Ideas from Ancient Philosophy to Contemporary Environmental Science," Environmental Conservation; Cambridge 38, no. 2, June. http://dx.doi.org/10.1017/S0376892911000245.

Hall, Edith, (2011). “'Master of Those Who Know': Aristotle as Role Model for the TwentyFirst Century Academician," European Review; Cambridge 25, no. 1 (February 2017): 319, http://dx.doi.org/10.1017/S1062798716000429.; Enrico Berti, “The Contemporary Relevance of Aristotle's Thought," Iris; Florence 3, no. 6. October .https:// search.proquest.com/docview/963357410/abstract/B61A78466FF942D0P Q/5.9.

Hazm, Ibnu " in Wikipedia bahasa Indonesia, ensiklopedia bebas, September 24, 2018, https://id.wikipedia.org/w/index.php?title=Ibnu_Hazm\&oldid=14210662.t

Hariyati, Mutty, (2017). "Sejarah Klasifikasi Ilmu-Ilmu Keislaman dan Perkembangannya Dalam Ilmu Perpustakaan” 9, no. 1 
Humaidi, (2015). Paradigma Sains Integratif Al Farabi. Jakarta: Sadra Press.

Khaldun, Ibnu" in Wikipedia bahasa Indonesia, ensiklopedia bebas, April 3, 2019, https:/ /id.wikipedia.org/w/index.php?title=Ibnu_Khaldun\&oldid=1496759

Lang, Helen. (2002). "Aristotle's Theory of the Unity of Science," Isis; Chicago 93, no.,March,https://search.proquest.com/docview/222947125/7FC4DCA04AE24F7C $\mathrm{PQ} / 14$.

Mohamad Ishaq, Usep and Wan Mohd Nor Wan Daud, (2017). "Ibn Al-Haytham's Classification of Knowledge," Al-Jami'ah: Journal of Islamic Studies 55, no. 1 (June 26, https://doi.org/10.14421/ajis.2017.551.189-210.

Osman Bakar, Osman, (1997). "Classification of Knowledge in Islam; a Study in Islamic Philosophies of Science, Diterjemahkan Oleh Purwanto, Dengan Judul: Hirarki Ilmu, Membangun Rangka Pikir Islamisasi Ilmu Menurut al Farabi, al Ghazali Dan Quthb al Dīn al Syirazi," Cet. I,.

Salminawati, (2012). Basis Ontologis Klasifikasi Ilmu Dalam Perspektif Islam (Studi Tentang Pemikiran Al-Farabi, Al-Ghazali, Dan Ibnu Khaldun)

Uun Fardiana, Iis, (2017). "Integralisme Ilmu Dalam Islam (Sejarah Perkembangan Dan Klasifikasi)," QALAMUNA - Jurnal Pendidikan, Sosial, Dan Agama 9, no. 1 (2017): 122 ,

http://ejournal.kopertais4.or.id/mataraman/index.php/qalamuna/article/view/3334.

Utsman Najati, Muhammad, (2013). Ad Dirasat an Nafsinnah 'Inda Ulama Muslimin (Al Qahirah: Dar Syuruq, 1993), 51-53.; Robert Hammond, The Philosophy of Al Farabi and Its Influence on Medieval Thought, S.l.: Literary licensing.

Zainal Abidin, Muhammad, (2011). "Konsep Ilmu Dalam Islam: Tinjauan Terhadap Makna, Hakikat, Dan Sumber-Sumber Ilmu Dalam Islam," Jurnal Ilmu Ushuluddin 10, no. 1.

Zagorin, Perez, (2001). "Francis Bacon's Concept of Objectivity and the Idols of the Mind," British Journal for the History of Science; Norwich 34, no. 123, December. https://search.proquest.com/docview/215735755/abstract/B287F344C13A4053PQ $/ 1$. 